18

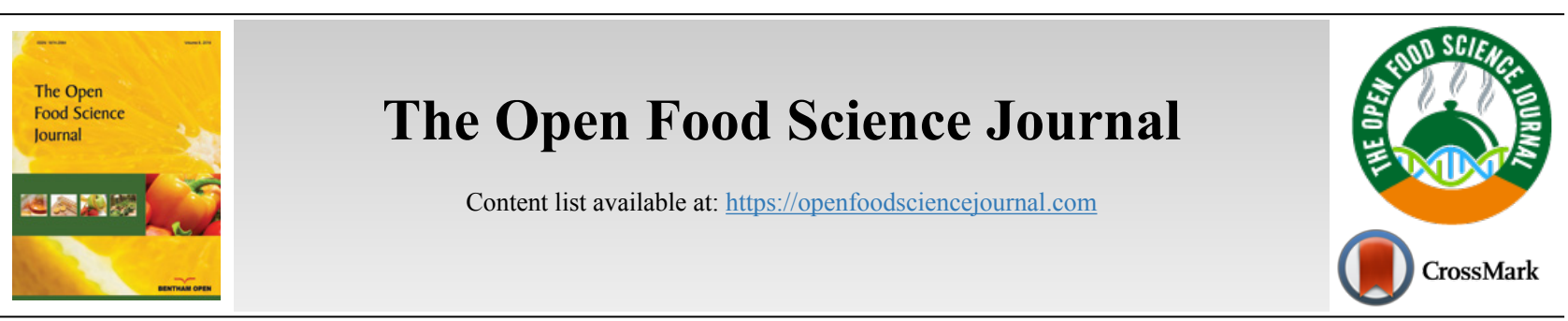

RESEARCH ARTICLE

\title{
Physical, Proximate and Sensory Properties of Cake Produced using Shea Butter as Shortening
}

Osunrinade Oludolapo A., ${ }^{1, *}$, Azeez Abibat O. ${ }^{1}$, Babalola Kafayat A. ${ }^{1}$ and Bamisaye Yemisi O. ${ }^{1}$

${ }^{1}$ The Oke-Ogun Polytechnic Saki, Food Science and Technology, Oyo State, Nigeria

\begin{abstract}
:
Background:

Shea butter is the under-consumed vegetable fat and oil. Making shea butter a part of food components in confectionaries would increase its utilization.

Objective:

In this study, the cake was produced by incorporating shea butter as shortening.

Methods:

Shea butter to margarine ratio was 100: $0,50: 50,40: 60,30: 70$, and 0:100\%, and additional cake samples were produced using flashed shea butter. Standard methods determined the physical and proximate properties of the cake samples, while 25 -member panelists did the sensory evaluation. Statistical significance was done at $\mathrm{p}<0.05$. The height, weight, and volume of the cake samples ranged from 3.2 to $3.9 \mathrm{~cm}, 39$ to $50 \mathrm{~g}$, and $625 \mathrm{~cm}$ to $1026 \mathrm{~cm}^{3}$, respectively. The ranges of moisture, fat, protein, carbohydrate, crude fiber, and the ash content of cakes were 13.7-17.3, 24.3- 30.7, 4.4-8.6, 43-50, 0.10-1.10, and 2.9-3.9\%, respectively. The energy value of cake samples in kcal ranged from 440 to 471 .

Results:

There was no significant difference ( $p>0.05$ ) in the height and volume of the cakes produced from $100 \%$ shea butter and $100 \%$ margarine. The fat, crude fiber, and ash content increase with the increase in Shea butter substitution. There was no significant difference in the taste and appearance of cake samples from $100 \%, 70 \%, 60 \%$, and $50 \%$ margarine.

Conclusion:

Cake samples produced with $60 \%$ margarine and $40 \%$ shea butter were the most liked by the consumers. Acceptable cakes can be produced by the
\end{abstract} inclusion of up to $50 \%$ shea butter as part of the shortening.

Keywords: Cake, Shea butter, Shortening, Margarine, Fat and oil, Sensory.

\begin{tabular}{|l|l|l|r}
\hline Article History & Received: July 30, 2020 & Revised: November 18, 2020 & Accepted: November 30, 2020
\end{tabular}

\section{INTRODUCTION}

Shea butter is underutilized when comparing its availability with its percentage contribution to edible fat and oil. Among other factors, poor sensory quality and low acceptability have been associated with food products from shea butter. This behavior is because fat contributes significantly to the organoleptic characteristics, micro and macrostructure of confectionaries [1].

One of the major confectionaries that utilize shortening is

\footnotetext{
* Address correspondence to the author at The Oke-Ogun Polytechnic Saki, Oyo
} State, Nigeria; E-mail: dolaps2004@yahoo.com cake. The cake can be categorized based on size; an example of such is the queen's cake, which is of a small size usually intended for individual consumption [2]. However, the quality of cakes is not very dependent on the sizes but its composition and production processes. During cake production, fat imparts tenderness, soft structure alongside flavor enhancement [3]. Creaming and emulsifying capacity of shortening in cake production have been reported to be the two most critical properties needed [4]. Majorly, fat is used in baking traps and retains air in the protein and starch structures of cakes [5]. On the other hand, fat has an influence on the color, aroma as well as serves as a medium of heat transfer $[6,7]$. 
Shea butter, a product from the nut of the African shea tree (Vitelaria paradoxa), has off-white or ivory-colored characteristics [8]. Shea butter has been commonly used mainly as edible oil, medicinal ointment, and as a raw material in soaps, margarine, pomade, and drug production [9]. Ifesan et al. [10] reported the use of Shea butter in the production of bread-spread. The occasional use of shea butter in the chocolate industry as a substitute for cocoa butter was reported by Maranz et al. [11]. These uses could be attributed to both its physical, functional, and compositional characteristics.

Garba et al. [12] reported a high postharvest loss of shea butter, while a more significant percentage of the remainder was exported at low prices locally. Commercial utilization of Shea butter would significantly improve national economic development. Its use in food would contribute to the gross domestic product of Nigeria and other producing nations. Despite the availability and low cost of shea butter [9], limitation in its use for baking processes has been caused by its off-flavor characteristics. Therefore, the present work studied the physical, proximate, and sensory properties of cakes produced from using shea butter at different percentages with and without commercially available margarine as shortening.

\section{MATERIALS AND METHODS}

\subsection{Materials}

Flour, sugar, commercially available margarine (Simas), eggs, baking powder, and shea butter were purchased from the sango market, Saki, Oyo State, Nigeria. Baking equipment and facilities of the bakery unit of The Oke-Polytechnic Saki, Oyo State, were used for queen's cake production.

\subsection{Cake Production}

Queen's Cakes were produced using the method described by Ceserani and Kinton [13]. The method is as briefly described in Fig. (1). The percentage of complementation levels of shea butter and margarine is presented in Table $\mathbf{1}$. Shea butter treated with heat (Flashed shea butter) was also used for cake production. Formulations for cake production for various samples are presented in Table 2.

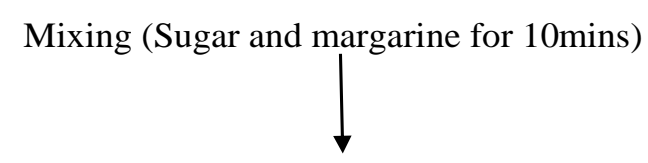

Egg whisking with flavor for 3 mins

Addition of whisked egg and flavor to margarine and sugar mixture<smiles>[3H][3H]</smiles>

Stir in with flour and baking powder

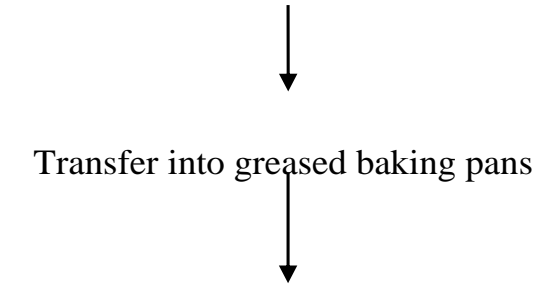

Baking

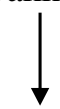

Cooling

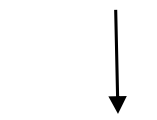

Packaging

Fig. (1). Cake preparation [13]. 
Table 1. Shortening mixture of shea butter and margarine.

\begin{tabular}{|c|c|c|}
\hline Samples Code & Shea butter (\%) & Margarine (\%) \\
\hline FLS & Flashed Shea butter (100\%) & 0 \\
\hline ODR & 100 & 0 \\
\hline FF1 & 50 & 50 \\
\hline MS6 & 40 & 60 \\
\hline SM3 & 30 & 70 \\
\hline
\end{tabular}

FLS: Flashed shea butter was obtained by heat treatment of shea butter up to its flashpoint

\subsection{Determination of Physical Property of Cake Samples}

Weight, height, and volume of the cake samples were the physical parameters measured. The method highlighted by Giami and Barber [14] with slight modification was used to measure the physical characteristics of the cake samples. All physical measurements were taken two hours after baking. The average of five cake samples was recorded for each measurement, and this was done in three replicates for all physical parameters. Digital weighing balance and meter rule were used to measure weight and height, respectively. The queen's cake volume was estimated using the cone equation presented in equation 1.0.

$$
\text { Volume of cake }\left(\mathrm{cm}^{3}\right)=\pi \mathrm{h}\left(\mathrm{d}^{2}+\mathrm{db}+\mathrm{b}^{2}\right)
$$

Where $\mathrm{d}$ and $\mathrm{b}$ are upper and lower diameters of cake, respectively,

$\mathrm{h}$ is the height of the cake and $\pi$ is 3.142

\subsection{Determination of the Proximate Composition of Cake Samples}

Queen's cake samples were analyzed to determine the moisture, ash, crude fiber, protein, fat, and carbohydrate. Briefly, the Kjeldahl method, as described by [15], was used for protein determination. Ash content was determined by using a muffle furnace at $600{ }^{\circ} \mathrm{C}$ for 3 hours, while moisture content determination was done by force air draft oven at $105^{\circ} \mathrm{C}$ for 4 hours [15]. Crude fiber and fat were also determined using AOAC [15], while the Carbohydrate content and energy value were obtained by difference and Atwater factor $(4,4,9)$, respectively.

Table 2. Formulation for cake production

\begin{tabular}{|c|c|c|c|c|c|c|}
\hline Ingredients & MGR & FLS & ODR & FF1 & MS6 & SM3 \\
\hline Flour (g) & 400 & 400 & 400 & 400 & 400 & 400 \\
\hline Sugar (g) & 200 & 200 & 200 & 200 & 200 & 200 \\
\hline Milk (g) & 50 & 50 & 50 & 50 & 50 & 50 \\
\hline Flavour (ml) & 3 & 3 & 3 & 3 & 3 & 3 \\
\hline Egg (g) & 300 & 300 & 300 & 300 & 300 & 300 \\
\hline Baking powder (g) & 5 & 5 & 5 & 5 & 5 & 5 \\
\hline Shea butter (g) & 0 & 250 & 250 & 125 & 100 & 75 \\
\hline Margarine (g) & 250 & 0 & 0 & 125 & 150 & 175 \\
\hline
\end{tabular}

\subsection{Sensory Evaluation}

A twenty-five-member panelist was used to assess cake samples' sensory attributes of appearance, aroma, taste, texture, and overall acceptability. The cake sample sensorial assessment was based on a 9-point hedonic scale quality analysis [16] with 9 representing liked extremely, and 1 representing disliked extremely. The panelists were individuals that are regular consumers of cakes and were neither sick nor allergic to any food. Necessary precautions were taken to prevent carryover of flavor during the tasting by ensuring that panelists rinse their mouth with water after each evaluation.

\subsection{Statistical Analysis}

Data were obtained in triplicates. All results were subjected to analysis of variance (ANOVA) and mean separation was done with Duncan multiple range test at $\mathrm{p}<0.05$ using the SPSS package.

\section{RESULTS AND DISCUSSION}

\subsection{Physical Properties of Cake Samples}

The result of the physical properties of the cake presented in Table 3 shows that height, weight, and volume of the cake samples ranged from 2.7 to $3.9 \mathrm{~cm}, 39$ to $50 \mathrm{~g}$, and $625 \mathrm{~cm}^{3}$ to $1026 \mathrm{~cm}^{3}$, respectively. The queen's cake samples top and bottom diameters had a range of 6.0-7.1 cm and 3.3 to $3.6 \mathrm{~cm}$, respectively. The lowest value of height $(2.7 \mathrm{~cm})$, weight (39 $\mathrm{g}$ ), and volume $\left(625 \mathrm{~cm}^{3}\right)$ was obtained when $50 \%$ of shea butter was incorporated as the shortening. Aside from when $100 \%$ shea butter was used, generally, height, weight, and volume decreased as the percentage of shea butter used increased.

The volume of the cake was highest $\left(1026 \mathrm{~cm}^{3}\right)$ for cake samples from flashed shea butter. Although Chinma et al. [17] reported that weight and volumes of baked products are a function of the bulk density of flour, however, the result of the present study identified the composition of the shortening agent as a factor that influenced weight and volume. This behavior could be linked to the reduced ability of shea butter substitution with margarine level to retain air in the cake batter. There was no significant difference $(p>0.05)$ in height and volume of cake produced from $100 \%$ shea butter and $100 \%$ margarine, whereas flashed shea butter cake had a significantly higher volume, which could be due to its higher ability to trap and retain air in the cake batter [18]. Tireki [3] also opined that shortening used in cake production affects the volume, crumb tenderness, and evenness of the cell structure.

Value of height of cake samples obtained in the present work is comparable to that reported by Kiin-kabari and Banigo [19] on the quality characteristics of cakes prepared from wheat and unripe plantain flour blends enriched with Bambara groundnut protein concentrate where the height of the control of that study was recorded as $3.8 \mathrm{~cm}$. 
Table 3. Result of physical properties of cakes.

\begin{tabular}{|c|c|c|c|c|c|c|}
\hline Samples & MGR & FLS & ODR & FF1 & MS7 & SM3 \\
\hline Height (cm) & $3.4^{\mathrm{bc}} \pm 0.3$ & $3.9^{\mathrm{a}} \pm 0.2$ & $3.5^{\mathrm{b}} \pm 0.2$ & $2.7^{\mathrm{d}} \pm 0.1$ & $3.2^{\mathrm{c}} \pm 0.2$ & $3.6^{\mathrm{b}} \pm 0.1$ \\
\hline Weight(cm) & $49^{\mathrm{a}} \pm 2$ & $42^{\mathrm{b}} \pm 4$ & $44^{\mathrm{b}} \pm 5$ & $39^{\mathrm{c}} \pm 9$ & $40^{\mathrm{c}} \pm 4$ & $50^{\mathrm{a}} \pm 2$ \\
\hline $\mathbf{D}_{\mathbf{1}}(\mathbf{c m})$ & $6.4^{\mathrm{bc}} \pm 0.7$ & $6.9^{\mathrm{ab}} \pm 0.6$ & $6.2^{\mathrm{c}} \pm 0.4$ & $6.5^{\mathrm{bc}} \pm 0.6$ & $6.0^{\mathrm{c}} \pm 0.2$ & $7.1^{\mathrm{a}} \pm 0.2$ \\
\hline $\mathbf{D}_{\mathbf{2}} \mathbf{( c m )}$ & $3.5^{\mathrm{a}} \pm 0.1$ & $3.5^{\mathrm{ab}} \pm 0.2$ & $3.6^{\mathrm{a}} \pm 0.3$ & $3.30^{\mathrm{b}} \pm 0.05$ & $3.4^{\mathrm{ab}} \pm 0.1$ & $3.50^{\mathrm{ab}} \pm 0.05$ \\
\hline Volume $\left(\mathbf{c m}^{\mathbf{3}}\right)$ & $812^{\mathrm{c}} \pm 1$ & $1026^{\mathrm{a}} \pm 0.5$ & $806.0^{\mathrm{c}} \pm 0.2$ & $625^{\mathrm{c}} \pm 2$ & $690^{\mathrm{d}} \pm 2$ & $973^{\mathrm{b}} \pm 2$ \\
\hline
\end{tabular}

*mean values in the same column with different superscripts are significantly different at $\mathrm{p}<0.05$. $\square$ MGR-100\% Margarine; ODR-100\% Shea butter; FLS- $100 \%$ Flashed Shea butter; FF1-50\% Shea butter $+50 \%$ Margarine; MS6- $40 \%$ Shea butter $+60 \%$ Margarine; SM3-30\% Shea butter $+70 \%$ margarine ; $\mathrm{D}_{1}=$ Top Diameter of Queen's cake; $\mathrm{D}_{2}=$ Bottom Diameter of Queen's cake

\subsection{Result of Proximate Composition of Cakes}

The moisture content, which is an index of keeping quality, differs significantly $(\mathrm{p}<0.05)$ for cake samples from $100 \%$ shea butter, $100 \%$ flashed shea butter, and $100 \%$ margarine. The ranges of moisture content of cakes were $13.7-17.3 \%$ in flashed shea butter shortening cake to margarine shortening cake, respectively. The range of moisture content (18.2-21.5\%) for cake samples prepared from wheat and cocoyam flour blends reported by Alozie and Chinma [20] is higher than that obtained in the present study. This result could be due to the heat transfer property of shea butter, which allowed the removal of moisture during baking. Since cake samples produced from $100 \%$ margarine had a moisture value closed to that reported in the literature [20] (Table 4).

There was a significant difference in fat, protein, carbohydrate, crude fiber, ash content, and energy value for cake samples from $100 \%$ shea butter, $100 \%$ flashed shea butter and $100 \%$ margarine. The protein content of all cake samples significantly differs at $\mathrm{p}<0.05$, with values ranging from $4.4-8.6 \%$ in samples flashed shea butter and margarine, respectively. The fat, crude fiber, and ash content increases with the increase in shea butter substitution. However, protein and carbohydrate content decreases with an increase in shea butter inclusion. Protein and carbohydrate content obtained in the present work was within the range of that reported by Alozie and Chinma [21], while the fat content obtained was higher than that reported in the literature [21]. This result could be due to the use of shea butter in the present study because fat content increases with the inclusion of shea butter. This fact could be linked to the fact that margarine has $80 \%$ fat in its composition [22]. And the energy value in kcal ranged from 440 to 472 for samples from margarine and flashed shea butter shortening, respectively.

\subsection{Sensory Properties of Cakes}

Cake samples from $100 \%, 70 \%$, and $60 \%$ margarine were not significantly different $(\mathrm{p}<0.05)$ in texture and overall acceptability as assessed by panelists. However, as the percentage of margarine in cake increases, the acceptability of cake samples' texture increases. This could be because shea butter has been shown to have a lesser ability to entrap air in the mixing process with sugar, which is supposed to help in the development of its fluffiness. Also, there was no significant difference in taste and appearance for cake samples from $100 \%, 70 \%, 60 \%$, and 50\% margarine (Table 5).

When compared with cake produced from $100 \%$ shea butter, cake baked with flashed shea butter is more acceptable in texture, aroma, taste, appearance, and overall acceptability. This could be attributed to the change in flavor characteristics of shea butter brought about by the heating process that took place with the flashed shea butter. Concerning all sensory properties assessed by the panelists, cake samples produced from $60 \%$ Margarine and $40 \%$ Shea butter were most liked by the consumers. Cake samples with $100 \%$ shea butter had the lowest acceptability for texture, aroma, taste, appearance, and overall acceptability. This is in agreement with Fold [23], who reported a noticeable reduction in the acceptability of chocolate produced by using shea butter. Hence, the lowest acceptability of cake from $100 \%$ shea butter could be due to the significant difference in the flavor characteristics of the cake sample.

Table 4. Proximate composition of cakes.

\begin{tabular}{|c|c|c|c|c|c|c|}
\hline Samples & MGR & ODR & FLS & FF1 & MS6 & SM3 \\
\hline Moisture Content (\%) & $17.3^{\mathrm{a}} \pm 0.4$ & $15.3^{\mathrm{b}} \pm 0.3$ & $13.7^{\mathrm{c}} \pm 0.6$ & $16.66^{\mathrm{ab}} \pm 0.01$ & $15.91^{\mathrm{b}} \pm 0.06$ & $15.8^{\mathrm{b}} \pm 0.3$ \\
\hline Protein(\%) & $8.6^{\mathrm{a}} \pm 0.1$ & $6.0^{\mathrm{e}} \pm 0.2$ & $4.43^{\mathrm{f}} \pm 0.1$ & $6.8^{\mathrm{d}} \pm 0.1$ & $7.4^{\mathrm{c}} \pm 0.3$ & $7.8^{\mathrm{b}} \pm 0.3$ \\
\hline Crude Fiber(\%) & $0.24^{\mathrm{e}} \pm 0.01$ & $1.11^{\mathrm{a}} \pm 0.03$ & $0.68^{\mathrm{c}} \pm 0.01$ & $0.81^{\mathrm{b}} \pm 0.03$ & $0.67^{\mathrm{c}} \pm 0.02$ & $0.48^{\mathrm{d}} \pm 0.01$ \\
\hline Fat(\%) & $24.3^{\mathrm{e}} \pm 0.4$ & $30.7^{\mathrm{a}} \pm 0.1$ & $28.1^{\mathrm{c}} \pm 0.2$ & $28.80^{\mathrm{b}} \pm 0.08$ & $27.69^{\mathrm{c}} \pm 0.08$ & $26.1^{\mathrm{d}} \pm 0.2$ \\
\hline Ash(\%) & $2.9^{\mathrm{e}} \pm 0.3$ & $3.9^{\mathrm{a}} \pm 0.4$ & $3.5^{\mathrm{b}} \pm 0.5$ & $3.6^{\mathrm{ab}} \pm 0.3$ & $3.4^{\mathrm{c}} \pm 0.1$ & $3.3^{\mathrm{d}} \pm 0.3$ \\
\hline Carbohydrate(\%) & $46.7^{\mathrm{b}} \pm 0.5$ & $43.0^{\mathrm{c}} \pm 0.7$ & $50^{\mathrm{a}} \pm 1$ & $44.0^{\mathrm{c}} \pm 0.6$ & $44.5^{\mathrm{c}} \pm 0.5$ & $46.3^{\mathrm{b}} \pm 0.5$ \\
\hline Energy(Kcal) & $440^{\mathrm{d}} \pm 1$ & $458^{\mathrm{b}} \pm 2$ & $472^{\mathrm{a}} \pm 1$ & $462^{\mathrm{ab}} \pm 2$ & $465^{\mathrm{ab}} \pm 2$ & $452^{\mathrm{c}} \pm 2$ \\
\hline
\end{tabular}

*mean values in the same column with different superscripts are significantly different at $\mathrm{p}<0.05$. $\square$ MGR-100\% Margarine; ODR-100\% Shea butter; FLS- $100 \%$ Flashed Shea butter; FF1-50\% Shea butter $+50 \%$ Margarine; MS6-40 $\%$ Shea butter $+60 \%$ Margarine; SM3-30\% Shea butter $+70 \%$ margarine 
Table 5. Sensory properties of cakes.

\begin{tabular}{|c|c|c|c|c|c|c|}
\hline SAMPLES & MGR & ODR & FLS & FF1 & MS6 & SM3 \\
\hline Texture & $7.53^{\mathrm{a}}$ & $6.11^{\mathrm{c}}$ & $6.54^{\mathrm{bc}}$ & $6.61^{\mathrm{bc}}$ & $7.69^{\mathrm{a}}$ & $7.04^{\mathrm{ab}}$ \\
\hline Aroma & $6.96^{\mathrm{ab}}$ & $6.00^{\mathrm{c}}$ & $6.77^{\mathrm{b}}$ & $7.04^{\mathrm{ab}}$ & $7.65^{\mathrm{a}}$ & $6.81^{\mathrm{b}}$ \\
\hline Taste & $7.46^{\mathrm{a}}$ & $6.27^{\mathrm{b}}$ & $7.04^{\mathrm{a}}$ & $7.11^{\mathrm{a}}$ & $7.77^{\mathrm{a}}$ & $7.27^{\mathrm{a}}$ \\
\hline Appearance & $7.88^{\mathrm{a}}$ & $7.00^{\mathrm{b}}$ & $7.08^{\mathrm{b}}$ & $7.31^{\mathrm{ab}}$ & $7.92^{\mathrm{a}}$ & $7.27^{\mathrm{ab}}$ \\
\hline Overall Acceptability & $7.61^{\mathrm{a}}$ & $6.81^{\mathrm{b}}$ & $7.26^{\mathrm{ab}}$ & $7.23^{\mathrm{ab}}$ & $8.00^{\mathrm{a}}$ & $7.38^{\mathrm{a}}$ \\
\hline
\end{tabular}

*mean values in the same column with different superscripts are significantly different at $\mathrm{p}<0.05$. $\square$ MGR-100\% Margarine; ODR-100\% Shea butter; FLS-100\% Flashed Shea butter; FF1-50\% Shea butter $+50 \%$ Margarine; MS6- $40 \%$ Shea butter $+60 \%$ Margarine; SM3-30 $\%$ Shea butter $+70 \%$ margarine

\section{CONCLUSION}

Cakes were produced from shea butter and margarine mixture as shortenings. From the results obtained, the use of shea butter as shortening in cake production gave products of comparable characteristics with that made from conventional shortening, i.e., margarine, and the panelists well accepted the products. However, shea butter quality may be improved upon by refining to have products that are more acceptable to the consumer, as seen with results obtained for cake produced from flashed shea butter shortening.

\section{ETHICS APPROVAL AND CONSENT TO PARTI- CIPATE}

Not applicable.

\section{HUMAN AND ANIMAL RIGHTS}

Not applicable.

\section{CONSENT FOR PUBLICATION}

Not applicable.

\section{AVAILABILITY OF DATA AND MATERIALS}

Not applicable.

\section{FUNDING}

None.

\section{CONFLICT OF INTEREST}

The authors declare no conflict of interest, financial or otherwise.

\section{ACKNOWLEDGEMENTS}

Declared none

\section{REFERENCES}

[1] Turabi E, Sumnu G, Sahin S. Quantitative analysis of macro and micro-structure of gluten freerice cakes containing different types of gums baked in different ovens. Food Hydrocoll 2010; 24: 755-62. [http://dx.doi.org/10.1016/j.foodhyd.2010.04.001]

[2] Eke J, Sanni SA, Owuno F. Proximate and sensory properties of banana cakes. Nigerian Food J 2009; 27: 102-6. [http://dx.doi.org/10.4314/nifoj.v27i2.47479]

[3] Tireki S. Technology of cake production.Food engineering aspects of baking sweet goods. $11^{\text {th }}$ ed. New York: CRC Press 2008; p. 104.

[4] Rios RV, Pessanha MD, Almeida PF, Viana CL, Lannes SC. Application of fats in some food products. Food Sci Technol
(Campinas) 2014; 34: 3-15.

[http://dx.doi.org/10.1590/S0101-20612014000100001]

[5] Cauvain SP. Cakes: nature of cakes: chemistry of baking.Encyclopedia of Food Sciences and Nutrition. $5^{\text {th }}$ ed. London: Elsevier Science 2003. [http://dx.doi.org/10.1016/B0-12-227055-X/00145-0]

[6] Charley H, Weaver C. Foods: a scientific approach. 3rd ed. New Jersey: Prentice-Hall 1998; p. 54.

[7] Okullo JBL, Omujal F, Agea JG, et al. Physico-chemical characteristics of shea butter (Vitellaria paradoxa C.F. Gaertn.) oil from the Shea district of Uganda. Afr J Food Agric Nutr Dev 2010; 10: 2070-84.

[http://dx.doi.org/10.4314/ajfand.v10i1.51484]

[8] Alfred T. Fats and Fatty Oils.Ullmann's Encyclopedia of Industrial Chemistry. Weinheim: Wiley-VCH, Posted 2002. Online

[9] Olaniyan AM, Oke K. Quality characteristics of shea butter recovered from shea kernel through dry extraction process. J Food Technol 2007; 44: 404-7.

[10] Ifesan OT, Fasasi OS, Ehoniyotan FA. Production of bread-spread from blends of shea butter (vitellaria paradoxa), garlic (allium sativum), ginger (zingiberOfficinale), scent leaf (occimumgratissimum), and suya spice. J Microbiol Biotechnol Food Sci 2012; 6: 1406-23.

[11] Maranz S, Wiesman Z, Bisgaard J, Bianchi G. Germplasm resources of Vitellaria paradoxa based of variations in fat composition across the species distribution range. Agrofor Syst 2004; 60: 71-6. [http://dx.doi.org/10.1023/B:AGFO.0000009406.19593.90]

[12] Garba ID, Nwawe CN, Oisakede IL. The potentials of shea nut tree to the Nigeria Economics. Int J Agricultural Econ Rural Develop 2011; 4: $62-77$.

[13] Ceserani V, Kinton R. Practial Cookery. $10^{\text {th }}$ ed. New York: John Wiley and Sons 2008; p. 82.

[14] Giami SY, Barber LI. Utilization of protein concentrates from ungerminated and germinated fluted pumpkin (Telfoririaoccidentalis Hook) seeds in cookies formulations. J Sci Food Agric 2004; 84: 1901-7.

[http://dx.doi.org/10.1002/jsfa.1881]

[15] AOAC. Association of Official Analytical Chemists. 18th ed. Washington, D.C., USA: A.O.A.C. 2005.

[16] Ihekoronye AI, Ngoddy PO. Integrated food science \& tech for the tropics. London: Macmillan Publishers 1985; pp. 265-92.

[17] Chinma CE, Ingbian EK, Akpapunam MA. Processing an acceptability of fried cassava balls ("Akara-akpu") supplemented with melon and soyabean flour. J Food Process Preserv 2007; 31: 143-56. [http://dx.doi.org/10.1111/j.1745-4549.2007.00117.x]

[18] Chinma CE, Abu JO, Abubakar YA. Effect of tigernut (Cyperusesculentus) flour addition on the quality of wheat-based cake. Int J Food Sci Technol 2010; 45: 1746-52.

[http://dx.doi.org/10.1111/j.1365-2621.2010.02334.x]

[19] Kiin-Kabari DB, Banigo EB. Quality characteristics of cakes prepared from wheat and unripe plantain flour blends enriched with bambara groundnut protein concentrate. Europ J Food Sci Technol 2015; 3: $1-10$.

[20] Alozie YE, Chinma CE. Proximate composition, physical and sensory properties of cake prepared from wheat and cocoyam flour blends. $\mathrm{J}$ Food Res 2015; 4: 7-12.

[http://dx.doi.org/10.5539/jfr.v4n5p181]

[21] Alozie YE, Udofia S, Lawal O, Ani IF. Nutrient composition and sensory properties of cakes made from wheat and African yam bean flour blends. J Food Technol 2009; 7: 115-8.

[22] Young N, Wassell P. Margarines and spreads.Food Emulsifiers and their applications. New York: Springer 2008; p. 75. 
[http://dx.doi.org/10.1007/978-0-387-75284-6_11]

[23] Fold N. A matter of good taste? Quality and the construction of standards for chocolate in the European Union. Cahiers d'Economie et Sociologie Rurales 2000; 55/56: 92-110.

\section{(C) 2020 Oludolapo et al.}

This is an open access article distributed under the terms of the Creative Commons Attribution 4.0 International Public License (CC-BY 4.0), a copy of which is available at: https://creativecommons.org/licenses/by/4.0/legalcode. This license permits unrestricted use, distribution, and reproduction in any medium, provided the original author and source are credited. 